\title{
Revalorization of cactus pear (Opuntia spp.) wastes as a source of antioxidants
}

\author{
Revalorização das sobras da palma forrageira (Opuntia spp.) como uma fonte de antioxidantes
}

\author{
Anaberta CARDADOR-MARTÍNEZ ${ }^{1,2 *}$, Cristian JIMÉNEZ-MARTÍNEZ ${ }^{3}$, Georgina SANDOVAL ${ }^{1}$
}

\begin{abstract}
Recently, an increased interest in antioxidant activity and health-improving capacity of cactus pear has been registered. The antioxidant capacity of the pulp of cactus-pear fruits has been previously assessed. In this work, total phenolics, flavonoids and tannins of peel and seeds of four cactus pear cultivars were examined as well as their antioxidant capacity. Tannins were the major phenolics in cactus pear seeds accounting for almost fifty percent for all cultivars. Analysis of variance revealed that ripeness, cultivar, and its interaction had highly significant effect on the total phenolics, tannin, and flavonoid contents of cactus pear peel. With regard to the seeds, only the stage of ripeness and interaction (ripeness stage x cultivar) were significant on total phenolics and tannins contents. The flavonoid content in seeds was not affected by any of the factors or their interactions. The antioxidant capacity was higher in the peel than in the seeds. Generally, fruits with light-green or yellow-brown peel have higher antiradical activity and Trolox equivalent antioxidant capacity (TEAC) values compared with those with red-purple peel. Cactus pear by-products can indeed be exploited as a good and cheap source of natural antioxidants.
\end{abstract}

Keywords: Cactus pear; peel; seeds; antioxidant capacity; phenolics; Opuntia.

\section{Resumo}

Recentemente, existe um crescente interesse na atividade antioxidante e na capacidade de melhora da saúde da palma forrageira. A capacidade antioxidante das polpas dos frutos da palma forrageira foi avaliada anteriormente. Neste trabalho, compostos fenólicos, flavonoides e taninos da casca e sementes de quatro cultivares da palma forrageira foram examinados, assim como a sua capacidade antioxidante. Os taninos foram os principais compostos fenólicos nas sementes da palma forrageira, representando quase $50 \%$ de todos os cultivares. A análise de variância revelou que a maturação, o cultivar e sua interação tiveram um efeito altamente significativo sobre o conteúdo dos fenóis totais, taninos e flavonoides da pele da palma forrageira. Em sementes, apenas o estágio de maturação e a interação (estágio de maturação x cultivar) foram significativos em fenólicos totais e taninos. O teor de flavonoides de sementes não foi afetado por nenhum dos fatores ou suas interações. A capacidade antioxidante foi maior na pele do que nas sementes. Geralmente, as frutas com casca verde-clara ou amarelo-marrom apresentam maior atividade antirradical e maior valor de capacidade antioxidante equivalente a Trolox (TEAC), quando comparadas com os frutos vermelho-púrpura. De fato, os subprodutos da palma forrageira podem ser explorados como uma fonte boa e barata de antioxidantes naturais. Palavras-chave: palma forrageira; casca; sementes; capacidade antioxidante; fenólicos; Opuntia.

\section{Introduction}

Cactus pear (Opuntia spp.), a member of the Cactaceae family, is a fruit crop used for subsistence agriculture in Mexico. Cactus pear is also cultivated worldwide on over 1,000,000 ha for fruits, forage and fodder consume. This data do not include the utilization of wild plants or those cultivated for self-consumption in the backyards of rural homes (INGLESE; BASILE; SCHIRRA, 2002). Cactus pear is a polyspecific fruit crop and Opuntia ficus-indica, O. megacantha, O. streptacantha and $O$. amyclaea are the most commonly cultivated opuntias (BRAVO-HOLLIS, 1978; PIMIENTA-BARRIOS, 1994). Cactus-pear cultivars produce clear-green, yellow-brown, yellow-orange, red-purple (PIMIENTA-BARRIOS, 1994)fruits, but the red-purple and yellow fruits are the most attractive in markets in the USA and Europe (PIMIENTA-BARRIOS, 1994; SÁENZ; SEPÚLVEDA, 2001).
The cactus-pear fruit is an oval, elongated berry, with a thick receptacle (peel), and juicy pericarp. The edible part (pulp) contains a relatively large number of seeds. The peel of commercially ripe fruits of Opuntia accounts for 33 to 55\% while the pulp accounts for 45 to $67 \%$; seeds, contained in the pulp, accounts for 2 to $10 \%$ (ARRIZON; CALDERÓN; SANDOVAL, 2006; PIGA, 2004). The cactus pear fruit is commonly consumed fresh; however, there is increased interest in the transformation into different products such as juice, jam, marmalade, and jelly among others (LÓPEZ-GONZÁLEZ; FUENTES-RODRÍGUEZ; RODRÍGUEZ-GÁMEZ, 1997; SAWAYA, et al., 1983). After being consumed or transformed, cactus pear peels and seeds are discarded although its seeds produce edible oil with high degree of insaturation. The most common fatty acids present are linoleic, oleic, palmitic, and stearic acid (PIMIENTA-BARRIOS, 1994). In addition, Opuntia

\section{Received 18/2/2010}

Accepted 9/7/2010 (004667)

${ }^{1}$ Centro de Investigación y Asistencia en Tecnología y Diseño del Estado de Jalisco

${ }^{2}$ Instituto Tecnológico y de Estudios Superiores de Monterrey Campus Querétaro, Epigmenio González, No. 500, San Pablo, Querétaro, México, 76130,

e-mail: mcardador@itesm.mx

${ }^{3}$ Departamento de Graduados e Investigación en Alimentos, Escuela Nacional de Ciencias Biológicas - IPN

${ }^{*}$ Corresponding author 
fruits and young stems have been traditionally used in folk medicine to treat diabetes, hypertension, asthma, burns, edema, and indigestion (CASTANEDA-ANDRADE; GONZALEZSANCHEZ; FRATI-MUNARI, 1997; GALATI et al., 2003; GALATI et al., 2001; TREJO-GONZÁLEZ et al., 1996).

Recently, there has been an increased interest in the antioxidant activity and health-improving capacity of cactus pear, and the antioxidant capacity of the pulp of cactuspear fruits has been assessed (ARRIZON; CALDERÓN; SANDOVAL, 2006; BUTERA et al., 2002; GALATI et al., 2003; LEE et al., 2002; STINTZING et al., 2005). Since some by-product constituents may be extracted and used as additives in food preparations or in the pharmaceutical and cosmetic sectors, the use of processed fruit by-products for human consumption has increased significantly in recent years. Cerezal and Duarte (2005) used the cactus pear pericarp to formulate marmalade. The seed meal seem to have potential use as a dietary fiber source for human consumption, for the extraction of oil (EL KOSSORI et al., 1998; RAMADAN; MÖRSEL, 2003a, 2003b), or for the extraction of D-xylans (HABIBI; MAHROUZ; VIGNON, 2002, 2005).

To our knowledge, there is limited literature on the study of the phenolics, tannins, and flavonoids, and associated antioxidant activity of cactus pear peel and seeds of different cactus pear cultivars. Thus, the main objectives of this study were: 1) determine the phenolic, tannin, and flavonoid contents in unripe and ripe seeds and fruit peels; 2) evaluate the free radical DPPH scavenging capacities of the extracts, 3 ) determine the radical cation $\mathrm{ABTS}^{++}$scavenging activities of the extracts, and 4) establish relationships between the antioxidant activities and total phenolic, tannin, or flavonoid contents.

\section{Materials and methods}

\subsection{Fruit collection}

Cactus pears were obtained from commercial plantation located at La Soledad, Villa de Graciano, San Luis Potosí, Mexico. Both peels and seeds were obtained from fruits from the cultivars named Montesa (yellow-brown), Cristalina (clear-green) and Pelón-liso (red-purple). Peel from Esmeralda (green-yellow) was also used. These cultivars were previously described by Pimienta-Barrios (1994) and Arrizon, Calderón and Sandoval (2006). Fruits were collected in the unripe and ripe stages of development, according with the criteria used for cactus pear growers.

The cactus pear peel was cut into small pieces and saved at $-20^{\circ} \mathrm{C}$ until extraction. The dry matter content of the peel was determined for the four cultivars under study on different samples according to standard methods. Seeds were removed from juice in a fruit pulper and dried until not further mass changes occurred. Seeds were ground and filtered through a 50-mesh sieve before analysis. The ground seed samples were stored at $-20^{\circ} \mathrm{C}$.

\subsection{Phenolic extraction from peels}

Ten grams (10 g) of the peel was treated with steam for 5 minutes in order to inactivate pectinolytic enzymes, and then extracted with $30 \mathrm{~mL}$ ethanol (70\%); the extract was maintained 24 hours in dark condition, filtered and concentrated in rotary evaporator until dryness. The residue was weighed and kept at $-20^{\circ} \mathrm{C}$ until analysis.

\subsection{Phenolic extraction from seeds}

One gram (1 g) of ground seeds was extracted with $\mathrm{HCl}(1 \%)$ methanol $(20 \mathrm{~mL})$ during 2 hours Samples $(0.2 \mathrm{~g})$ were extracted with methanol $(10 \mathrm{~mL}), 2$ hours in the dark, using a magnetic stirrer at room temperature (CARDADOR-MARTINEZ; LOARCA-PINA; OOMAH, 2002). The methanolic seed extracts were filtered and stored in the dark at $-20^{\circ} \mathrm{C}$ until analysis.

\subsection{Total phenolics}

Ten milligrams (10 mg) of peel extract were dissolved in 1 $\mathrm{mL}$ methanol previous to phenolic determination. Total phenols content was estimated by using the Folin-Ciocalteu colorimetric method (SINGLETON et al., 1999). Briefly, the $0.02 \mathrm{~mL}$ of the extracts was oxidized with $0.1 \mathrm{~mL}$ of $0.5 \mathrm{~N}$ Folin-Ciocalteu reagent, and then the reaction was neutralized with $0.3 \mathrm{~mL}$ sodium carbonate solution (20\%). The absorbance values were obtained by the resulting blue color measured at $760 \mathrm{~nm}$ with a Genesys 10 UV spectrophotometer (Rochester, NY, USA) after incubation for 2 hours at $25^{\circ} \mathrm{C}$. Quantification was done on the basis of a standard curve of gallic acid (SINGLETON et al., 1999). Results were expressed as mg of gallic acid equivalent per $100 \mathrm{~g}$ of dry weight.

\subsection{Flavonoids}

The spectrophotometric assay for the quantitative determination of flavonoid content described previously (EL HARIRI; SALLÉ; ANDARY, 1991) and adapted for its use with microplates (OOMAH; CARDADOR-MARTÍNEZ; LOARCA-PIÑA, 2005) was used, mixing $0.05 \mathrm{~mL}$ of the methanolic extract with $0.18 \mathrm{~mL}$ of distilled water and $0.02 \mathrm{~mL}$ of a solution of $10 \mathrm{~g} \cdot \mathrm{L}^{-1} 2$-aminoethyldiphenylborate in a 96-well microtitration flat-bottom plate (Corning). The absorbance of the solution was monitored at $404 \mathrm{~nm}$ with a spectrophotometer (680 XR Microplate Reader, Bio-Rad Laboratories, Inc). The absorption of the extract was compared with that of a rutin standard at concentrations ranging from 0 to $0.05 \mathrm{~g} . \mathrm{mL}^{-1}$. Flavonoid content was expressed as mg rutin equivalent per $100 \mathrm{~g}$ of dry sample.

\subsection{Tannins}

Condensed tannins were quantified by spectrophotometry using a Genesys 10 UV spectrophotometer (Rochester, NY, USA) according to Deshpande and Cheryan $(1985,1987)$. $1 \mathrm{~mL}$ aliquots of extracts or standard were dispensed into assay tubes and each sample was added with $5 \mathrm{~mL}$ of freshly prepared vanillin reagent $(1 \%$ vanillin solution was mixed with one part of $8 \% \mathrm{HCl}$ solution). The reaction was developed at $30^{\circ} \mathrm{C}$ for 30 minutes. To correct for potential interferences from natural pigments in cactus pear peel and seeds, a blank sample was prepared by subjecting the original extract to the same conditions of reaction, using $5 \mathrm{~mL}$ of $4 \% \mathrm{HCl}$ solution instead of the vanillin reagent. Absorbance of samples and blanks were 
read at $500 \mathrm{~nm}$. The absorbance of the blanks is subtracted from the absorbance corresponding of the vanillin-containing sample. The $(+)$-catechin was used as a reference standard and tannins were expressed as $\mathrm{mg}$ catechin equivalent per $100 \mathrm{~g}$ of dry matter.

\subsection{Free radical DPPH scavenging capacity}

2,2- Diphenyl-1-picrylhydrazyl (DPPH) is a free radical used for assessing antioxidant activity. Reduction of DPPH by an antioxidant or by a radical species results in a loss of absorbance at $515 \mathrm{~nm}$. Determination of antioxidant capacity, previously adapted for microplates (FUKUMOTO; MAZZA, 2000), was performed as follows: $0.02 \mathrm{~mL}$ of extract $(500 \mu \mathrm{M}$ gallic acid equivalent) or standards (BHT, gallic acid or $(+)$-catechin $500 \mu \mathrm{M}$ ) were added to a 96-well flat-bottom plates containing $0.2 \mathrm{~mL}$ of DPPH solution (125 $\mu \mathrm{M}$ DPPH in $80 \%$ methanol). Samples were prepared in triplicate. The plate was covered, left in the dark at room temperature and read after 90 minutes in a visible-UV microplate reader (680 XR Microplate Reader, Bio-Rad Laboratories, Inc) using a $520 \mathrm{~nm}$ filter. Data are expressed as a percentage of DPPH.discoloration (BURDA; OLESZEK, 2001).

\subsection{Radical cation $\mathrm{ABTS}^{+{ }^{+}}$scavenging activity}

The Trolox equivalent antioxidant capacity (TEAC) method is based on the ability of an antioxidant to scavenge the preformed radical cation ABTS ${ }^{*+}$ relative to that of the standard antioxidant Trolox. The total antioxidant capacity of both peel and seed extracts was realized according to the improved ABTS ${ }^{+}$method described by Re et al. (1999), and adapted for its use in microplates. Briefly, ABTS ${ }^{+}$radical cation was produced by reacting $7 \mathrm{mM}$ of $2,2^{\prime}$-azinobis(3-ethylbenzothiazoline6-sulfonic acid) diammonium salt (ABTS) and $2.45 \mathrm{mM}$ potassium persulfate after incubation at room temperature in dark for 16 hours. The ABTS ${ }^{+}$solution was diluted with ethanol to an absorbance of $0.80 \pm 0.1$ at $734 \mathrm{~nm}$. Standards and samples were prepared at 250 and $500 \mu \mathrm{M}$ in methanol, respectively. The $0.2 \mathrm{~mL}$ reagent and the $0.02 \mathrm{~mL}$ standard $(\mathrm{BHT},(+)$-catechin or gallic acid) or sample solutions were added to the well in a 96-microwell plate and mixed thoroughly. The absorbance readings were taken at $734 \mathrm{~nm}$ immediately after and 6 minutes after using a visible-UV microplate reader (680 XR Microplate Reader, Bio-Rad Laboratories, Inc.). Trolox standard solutions in methanol were prepared and assayed under the same conditions
(0-700 $\mu \mathrm{M})$. The Trolox-equivalent antioxidant capacity (TEAC) of the sample was calculated as the $\mu \mathrm{M}$ of Trolox needed to give the same degree of discoloration than samples at $500 \mu \mathrm{M}$ or standards at $250 \mu \mathrm{M}$.

Data were subjected to ANOVA and where significant differences existed, means were separated by the Tukey test. Statistical analysis was performed using StatGraphics Centurion $\mathrm{XV}$ version 15.0.10.

\section{Results and discussion}

\subsection{Phenolic content}

The highest values of phenolic content were observed in peels of the cultivar Esmeralda in the unripe stages and the lowest in the Pelón-Liso in the unripe stage also. Intermediant values were found in the Amarilla-Montesa, peles in both the ripe and unripe stages (Table 1) Tannin concentration of peels of the cultivars Pelón-Liso and Amarilla-Montesa in the ripe stages were statistically similar and highest than the rest of the cultivars. The flavonoid content was statistically superior in the peels of the cultivar Esmeralda in both the ripe and unripe stages. Low values of flavonoids were measured in the peels of the Pelón-Liso in the unripe stages (Table 1). Tannins percentage in relation to total phenolics was statically the highest in the Pelón-Liso in the ripe stage and the lowest in the Esmeralda ripe stage followed by Cristalina in both ripe and unripe stages (Table 1); however, the percentage of flavonoids in relation to Total phenolics showed to be the highest in the peels of the Cristalina in both ripe and unripe stages compared with the rest of cultivars (Table 1). These values are very close to the values observed for peach, nectarine, and plum peel ranging from 418 to $3323 \mathrm{mg} . \mathrm{kg}^{-1}$ (GIL et al., 2002), and similar to values obtained for juice from clear-green and red-purple cactus pear cultivars (STINTZING, et al., 2005) and Opuntia stems extracts (LEE et al., 2002).

Extracts of Pelón-Liso ripe and Montesa ripe showed the highest content of tannins in the peel, while white cactus pear peel cultivar (Cristalina) had the lowest content. Similar trends were observed when tannin concentration was expressed as percent in relation to total phenolic content (Table 1).

Values for flavonoid content in cactus pear peel varied from 7.64 to $66.38 \mathrm{mg}$ rutin equivalents per $100 \mathrm{~g}$ of dry weight

Table 1. Phenolic content in cactus pear peels.

\begin{tabular}{|c|c|c|c|c|c|c|}
\hline \multirow[t]{2}{*}{ Sample } & \multirow{2}{*}{$\begin{array}{l}\text { Ripeness } \\
\text { stage }\end{array}$} & \multicolumn{3}{|c|}{ Concentration $^{1}$} & \multicolumn{2}{|c|}{ \% Content ${ }^{2}$} \\
\hline & & $\begin{array}{c}\text { Total } \\
\text { phenolics }\end{array}$ & Tannins & Flavonoids & Tannin & Flavonoid \\
\hline \multirow[t]{2}{*}{ Esmeralda } & Ripe & $362^{\mathrm{a}}$ & $53^{c}$ & $66^{a}$ & $15^{\mathrm{e}}$ & $18^{\mathrm{b}, \mathrm{c}}$ \\
\hline & Unripe & $376^{\mathrm{a}}$ & $95^{\mathrm{b}}$ & $57^{\mathrm{b}}$ & $25^{\mathrm{d}}$ & $15^{\mathrm{c}, \mathrm{d}}$ \\
\hline \multirow[t]{2}{*}{ Pelón-Liso } & Ripe & $194^{c}$ & $144^{\mathrm{a}}$ & $21^{\mathrm{d}}$ & $74^{\mathrm{a}}$ & $11^{\mathrm{e}}$ \\
\hline & Unripe & $44^{c}$ & $23^{\mathrm{e}}$ & $8^{e}$ & $52^{c}$ & $17^{c}$ \\
\hline \multirow[t]{2}{*}{ Cristalina } & Ripe & $141^{\mathrm{d}}$ & $30^{\mathrm{d}, \mathrm{e}}$ & $36^{c}$ & $21^{\mathrm{d}, \mathrm{e}}$ & $26^{\mathrm{a}}$ \\
\hline & Unripe & $172^{c}$ & $32^{\mathrm{d}}$ & $36^{c}$ & $19^{\mathrm{d}, \mathrm{e}}$ & $21^{\mathrm{b}}$ \\
\hline \multirow[t]{2}{*}{ Montesa } & Ripe & $229^{b}$ & $144^{\mathrm{a}}$ & $35^{c}$ & $63^{\mathrm{b}}$ & $15^{\mathrm{d}}$ \\
\hline & Unripe & $223^{\mathrm{b}}$ & $52^{\mathrm{c}}$ & $32^{c}$ & $23^{\mathrm{d}}$ & $14^{\mathrm{d}}$ \\
\hline
\end{tabular}

${ }^{1}$ Concentration expressed as mg equivalent of gallic acid, catechin or rutin for total phenolics, tannins and flavonoids, respectively, per $100 \mathrm{~g}$ of peel in dry basis. ${ }^{2}$ Percentage of tannins and flavonoids in relation to total phenolics. Means in a column followed by the same letter are not significantly different (Tukey, $\alpha=0.05$ ). 
for Lisa unripe and Esmeralda ripe, respectively. Like for total phenolics Esmeralda peel had the higher flavonoid content. When the flavonoid concentration was expressed as mg rutin equivalent/100 g, there was no significant difference between Montesa and Cristal cultivars, however when it was changed into percent, the Cristalina cultivar in the ripe stage had a higher value than the other samples (Table 1).

Total polyphenols in the peel extracts, based on dry weight, remained nearly constant from unripe to ripe stages in clear-green and yellow-brown cultivars, decreasing a little in white cultivar and increased in red peel cultivar. Regarding tannin and flavonoid results, the content increased from unripe to ripe in Esmeralda and Pelón-liso peel, remained constant in Cristalina, decreasing in Amarilla-Montesa peel (Table 1).

Significant differences for total phenolic concentration in seeds were observed among cultivars. The range was much closer than the phenolics values in the peel, varying from 337 to $460 \mathrm{mg} . \mathrm{g}^{-1}$ for the Pelón-Liso and Montesa in the unripe stages, respectively (Table 2). The total phenolics in cactus pears were, on average, almost two times higher in seeds than in peels (389 mg. $100 \mathrm{~g} \mathrm{~g}^{-1}$ and $217 \mathrm{mg} .100 \mathrm{~g}^{-1}$ respectively). Analogous results were observed for the average contents of tannin and flavonoid, similarly to Muscadine grape seed which had five times the phenolic content showed by peel (PASTRANA-BONILLA et al., 2003). Unripe seeds had higher total phenolic concentration than ripe ones, coinciding with previous observations that indicate that the proanthocyanidin concentration decreases in grape peels and seeds during ripening (KATALINIC; MALES, 1997; KENNEDY; MATTHEWS; WATERHOUSE, 2000).

Tannins were the major phenolics in cactus pear seeds accounting for almost fifty percent for all cultivars, except for unripe Montesa (30\%). Flavonoids represented approximately $12 \%$ of total phenolics in seeds; there were not differences among either cultivars or ripeness stage (Table 2). However, Kuti (1992) reported that flavonoid content in fresh fruits was higher in red-purple peels of cactus pear cultivar than clear-green, red and yellow-peeled fruits.

The analysis of variance revealed that ripeness (R), cultivar $(\mathrm{C})$ and the interaction $(\mathrm{R} \times \mathrm{C})$ had highly significant effect $(\mathrm{p}<0.0001)$ on the total phenolic, tannin and flavonoid contents of cactus pear peel. In seed, ripeness stage was highly significant on total phenolic and tannin contents $(\mathrm{p}<0.0001)$, whereas cultivar was significant only on total phenolics $(\mathrm{p}<0.0001)$; the interaction, cultivar $\mathrm{x}$ ripeness stage, was statistically significant on total phenolic and tannin concentration. Flavonoid seed content was not affected by any of the factors or its interaction.

Changes in phenolic compounds during fruit development and ripening in apple (AWAD et al., 2001), revealed that the flavonols were highest in young fruits, and decreased as fruit grows, reaching a steady levels during maturation and ripening. Concerning anthocyanins, strawberry, blackberry, raspberry (WANG; LIN, 2000) and bush butter (MISSANG; GUYOT; RENARD, 2003) showed significant accumulations of anthocyanin during ripening. Both genetic, agronomic and environmental factors play important roles in the phenolic composition and thus nutritional quality of fleshly fruits (TOMÁS-BARBERÁN; ESPÍN, 2001).

Previous studies on the chemical composition on fresh fruits and juice of O. ficus-indica revealead that the microconstituents amounts in the juice are affected by the methods used for the processing of the juice (EL KOSSORI et al., 1998; GALATI et al., 2003; GURRIERI et al., 2000; HERNÁNDEZ-PÉREZ et al., 2005), although the stage of ripening, the storage temperature, the cultivar, and the place of origin, may affects the amounts of microconstituents in the juice also (HERNÁNDEZ-PÉREZ et al., 2005; KUTI, 1992).

\subsection{Antioxidant capacity}

Scavenging capacity was evaluated as percent discoloration of a free radical DPPH solution and expressed as antiradical activity (\% ARA). Unripe Esmeralda peels extracts had the highest value for antiradical activity amongst samples, which was similar to that of BHT, but lower than $(+)$-catechin and gallic acid antiradical activities. Peel extract of unripe Montesa and ripe Cristalina showed a mean value of $33 \%$, twice than the other samples (Table 3). Similar tendency was observed for ABTS cation scavenging assay where Esmeralda and Montesa peel extracts showed the highest values amongst samples, and comparable with catechin TEAC value. The TEAC values for Pelón-Liso extracts were the lowest for both the ripe and unripe stages.

Fruits with clear-green peels or yellow-brown give higher antiradical activity and TEAC values compared with red-purple fruits, coinciding with the observations of Butera et al. (2002).

In cactus pear seed extracts the antiradical activity ranged between a short intervals (32-38\%); the average was almost three times less than the activity showed by the standards. However, it was, at least, $10 \%$ higher than peel antiradical

Table 2. Phenolic content in cactus pear seeds.

\begin{tabular}{|c|c|c|c|c|c|c|}
\hline \multirow[t]{2}{*}{ Sample } & \multirow{2}{*}{$\begin{array}{l}\text { Ripeness } \\
\text { stage }\end{array}$} & \multicolumn{2}{|c|}{ Concentration $^{1}$} & \multicolumn{3}{|c|}{$\%$ Content $^{2}$} \\
\hline & & Total phenolics & Tannins & Flavonoids & Tannin & Flavonoid \\
\hline \multirow[t]{2}{*}{ Pelón-Liso } & Ripe & $345^{\mathrm{d}}$ & $171^{\mathrm{b}}$ & $46^{\mathrm{a}}$ & $50^{\mathrm{a}}$ & $13^{\mathrm{a}}$ \\
\hline & Unripe & $414^{\mathrm{b}}$ & $205^{\mathrm{a}}$ & $47^{\mathrm{a}}$ & $49^{\mathrm{a}}$ & $11^{\mathrm{b}}$ \\
\hline \multirow[t]{2}{*}{ Cristalina } & Ripe & $337^{\mathrm{d}}$ & $174^{\mathrm{a}, \mathrm{b}}$ & $46^{\mathrm{a}}$ & $52^{\mathrm{a}}$ & $14^{\mathrm{a}}$ \\
\hline & Unripe & $373^{c}$ & $169^{\mathrm{b}}$ & $49^{\mathrm{a}}$ & $45^{\mathrm{a}}$ & $13^{\mathrm{a}}$ \\
\hline \multirow[t]{2}{*}{ Montesa } & Ripe & $373^{c}$ & $172^{\mathrm{b}}$ & $49^{\mathrm{a}}$ & $46^{\mathrm{a}}$ & $13^{\mathrm{a}}$ \\
\hline & Unripe & $460^{\mathrm{a}}$ & $137^{c}$ & $50^{\mathrm{a}}$ & $30^{\mathrm{b}}$ & $11^{\mathrm{b}}$ \\
\hline
\end{tabular}

${ }^{1}$ Concentration expressed as mg equivalent of gallic acid, catechin and rutin for total phenolics, tannins and flavonoids, respectively, per $100 \mathrm{~g}$ of seeds in dry basis. ${ }^{2}$ Percentage of tannins and flavonoids in relation to total phenolics. Means in a column followed by the same letter are not significantly different (Tukey, $\alpha=0.05$ ). 
Table 3. Antioxidant capacity of cactus pear peel extracts.

\begin{tabular}{lccc}
\hline \multicolumn{1}{c}{ Sample $^{\mathrm{l}}$} & Ripeness stage & ARA $^{2}$ & TEAC $^{3}$ \\
\hline BHT & - & $59^{\mathrm{c}}$ & $299^{\mathrm{d}}$ \\
Catechin & - & $67^{\mathrm{b}}$ & $577^{\mathrm{b}}$ \\
Gallic acid & - & $91^{\mathrm{a}}$ & $646^{\mathrm{a}}$ \\
Esmeralda & Ripe & $21^{\mathrm{e}}$ & $322^{\mathrm{d}}$ \\
& Unripe & $49^{\mathrm{c}}$ & $534^{\mathrm{b}, \mathrm{c}}$ \\
Pelón-Liso & Ripe & $14^{\mathrm{f}}$ & $291^{\mathrm{d}}$ \\
& Unripe & $13^{\mathrm{f}}$ & $380^{\mathrm{d}}$ \\
Cristalina & Ripe & $33^{\mathrm{d}}$ & $430^{\mathrm{c}, \mathrm{d}}$ \\
& Unripe & $15^{\mathrm{f}}$ & $313^{\mathrm{d}}$ \\
Montesa & Ripe & $14^{\mathrm{f}}$ & $484^{\mathrm{c}}$ \\
& Unripe & $33^{\mathrm{d}}$ & $529^{\mathrm{b}, \mathrm{c}}$ \\
\hline
\end{tabular}

${ }^{1}$ Concentration for standards was $250 \mu \mathrm{M}$, and for extracts it was $500 \mu \mathrm{M}$ equivalent gallic acid. ${ }^{2} \mathrm{ARA}=$ Antiradical activity expressed as percent $\mathrm{DPPH} \cdot$ discoloration. ${ }^{3} \mathrm{TEAC}=$ Trolox antioxidant equivalent capacity in $\mu \mathrm{M}$ of Trolox equivalent to peel extract at $500 \mu \mathrm{M}$, or standards at $250 \mu \mathrm{M}$. Means in a column followed by the same letter are not significantly different (Tukey, $\alpha=0.05$ ).

Table 4. Antioxidant activity in cactus pear seed extracts.

\begin{tabular}{lccc}
\hline \multicolumn{1}{c}{ Sample $^{1}$} & Ripeness stage & ARA $^{2}$ & TEAC $^{3}$ \\
\hline BHT & - & $59^{\mathrm{c}}$ & $299^{\mathrm{c}}$ \\
Catechin & - & $67^{\mathrm{b}}$ & $577^{\mathrm{b}}$ \\
Gallic acid & - & $91^{\mathrm{a}}$ & $647^{\mathrm{a}}$ \\
Pelón-Liso & Ripe & $38^{\mathrm{d}}$ & $47^{\mathrm{d}}$ \\
& Unripe & $32^{\mathrm{e}}$ & $45^{\mathrm{d}}$ \\
Cristalina & Ripe & $32^{\mathrm{e}}$ & $24^{\mathrm{e}}$ \\
& Unripe & $36^{\mathrm{d}}$ & $40^{\mathrm{d}}$ \\
Montesa & Ripe & $38^{\mathrm{d}}$ & $19^{\mathrm{e}}$ \\
& Unripe & $32^{\mathrm{e}}$ & $12^{\mathrm{e}}$ \\
\hline
\end{tabular}

${ }^{1}$ Concentration of standards was $250 \mu \mathrm{M}$ and for samples it was $500 \mu \mathrm{M}$ equivalent gallic acid. ${ }^{2} \mathrm{ARA}=$ Antiradical activity expressed as percent $\mathrm{DPPH} \cdot$ discoloration. ${ }^{3} \mathrm{TEAC}=$ Trolox antioxidant equivalent capacity in $\mu \mathrm{M}$ of Trolox equivalent to seeds extract at $500 \mu \mathrm{M}$, or standards at $250 \mu \mathrm{M}$. Means in a column followed by the same letter are not significantly different (Tukey, $\alpha=0.05$ ).

activity at the same concentration (24 and 35\% for peel and seeds, respectively). Although the concentration tested for seed extracts in ABTS assay was $500 \mu \mathrm{M}$ ( $\mu \mathrm{M}$ equivalent gallic acid), all samples showed very low TEAC values, as low as $11.8 \mu \mathrm{M}$ (Table 4$)$, which means that the average in seeds $(31 \mu \mathrm{M})$ was 13 times lower than the mean value in peel $(410 \mu \mathrm{M})$. These results suggested the presence of compounds other than phenolics in peel extracts that might contributed to scavenge ABTS radical cations, as betalains or ascorbic acid that are commonly found in cactus pear pulp and juice (BUTERA et al., 2002; STINTZING et al., 2005).

Analysis of variance resulted in a significant effect of cultivar, ripeness stage and their interaction on both, antiradical activity and TEAC of peel extracts ( $\mathrm{p}<0.0001)$, whereas in seeds, only ripeness and the interaction or cultivar and the interaction were significant for ARA and TEAC, respectively $(\mathrm{p}<0.0001)$.

To obtain an overall perspective on the antioxidant properties and the respective chemical constituents, pairwise correlations between all these variables were realized for peels (Table 5) and seeds (Table 6). A significant relationship between total phenolics and flavonoids was observed in both, peels
Table 5. Correlation coefficients for total phenolics, flavonoids, tannins, and antioxidant activities in cactus pear fruit peel.

\begin{tabular}{lcccc}
\hline & Tannin & Flavonoid & \multicolumn{2}{c}{ Antioxidant activities } \\
\cline { 4 - 5 } & content & content & ARA & TEAC \\
\hline Total phenolics & $0.3441^{\mathrm{c}}$ & $0.8820^{\mathrm{a}}$ & $0.5210^{\mathrm{a}}$ & 0.2323 \\
Tannin content & - & 0.0296 & -0.0934 & 0.1058 \\
Flavonoids & - & - & $0.5036^{\mathrm{b}}$ & 0.1305 \\
ARA & - & - & - & $0.6377^{\mathrm{a}}$ \\
\hline
\end{tabular}

${ }^{\mathrm{a}} \mathrm{p}<0.0001 .{ }^{\mathrm{b}} \mathrm{p}<0.001 .{ }^{\mathrm{c}} \mathrm{p}<0.05 .(\mathrm{n}=48)$.

Table 6. Correlation coefficients for total phenolics, tannins, flavonoids and antioxidant activities for cactus pear seeds.

\begin{tabular}{lcccc}
\hline & Tannin & Flavonoid & \multicolumn{2}{c}{ Antioxidant activities } \\
\cline { 4 - 6 } & content & content & ARA $^{*}$ & TEAC $^{* *}$ \\
\hline Total phenolics & -0.2135 & $0.4009^{\mathrm{a}}$ & $-0.4669^{\mathrm{a}}$ & $-0.3506^{\mathrm{a}}$ \\
Tannin content & - & $-0.3672^{\mathrm{a}}$ & -0.1740 & $0.5037^{\mathrm{a}}$ \\
Flavonoid content & - & - & 0.0210 & -0.2210 \\
ARA & - & - & - & 0.1713 \\
\hline
\end{tabular}

${ }^{\star}$ ARA $=$ Antiradical activity. ${ }^{*}$ TEAC $=$ Tolox Equivalent Antioxidant Capacity. ${ }^{\text {a }} \mathrm{p}<0.05$ $(\mathrm{n}=36)$.

and seeds. However, only a significant correlation between flavonoid content and ARA was observed. In the case of seeds, a correlation between total phenolics and ARA, total phenolics and TEAC, and tannin content with ARA and TEAC were found (Table 6). All of the coefficients were modest, being 0.88 ( $\mathrm{p}<0.0001)$ the highest. Stintzing et al. (2005) reported high correlation coefficients (higher than 0.9) not only for chemical constituents (betalains, ascorbic acids and total phenolics) but also for these constituents and antioxidant activities in cactus pear juice and pulp.

\section{Conclusions}

We conclude that the value of Opuntia cactus pear by-products as a good and cheap source of natural antioxidants could be industrially exploited. However, before considering incorporation of cactus pear by-products as a dietary complement or as natural food antioxidant, it is necessary to carry out further studies in order to test their in vivo activity, bioavailability, and toxicity also.

\section{Acknowledgements}

This work was supported by Fundación Produce San Luis Potosí.

\section{References}

ARRIZON, J.; CALDERÓN, C.; SANDOVAL, G. Effect of different fermentation conditions on the kinetic parameters and production of volatile compounds during the elaboration of a prickly pear distilled beverage. Journal of Industrial Microbiology and Biotechnology, v. 33, n. 11, p. 921-928, 2006. http://dx.doi. org/10.1007/s10295-006-0153-9

AWAD, M. A. et al. Flavonoid and chlorogenic acid changes in skin of 'Elstar' and 'Jonagold' apples during development and ripening. Scientia Horticulturae, v. 90, n. 1-2, p. 69-83, 2001. 
BRAVO-HOLLIS, H. El Cultivo de la tuna. In: UNIVERSIDAD NACIONAL AUTÓNOMA DE MÉXICO - UNAM. (Ed.). Las cactaceas de México. Mexico City: UNAM, 1978. p. 132-161.

BURDA, S.; OLESZEK, W. Antioxidant and Antiradical Activities of Flavonoids. Journal of Agricultural and Food Chemistry, v. 49, n. 6, p. 2774-2779, 2001. http://dx.doi.org/10.1021/jf001413m

BUTERA, D. et al. Antioxidant Activities of Sicilian Prickly Pear (Opuntia ficus indica) Fruit Extracts and Reducing Properties of Its Betalains:\&nbsp; Betanin and Indicaxanthin. Journal of Agricultural and Food Chemistry, v. 50, n. 23, p. 6895-6901, 2002. http://dx.doi.org/10.1021/jf025696p

CARDADOR-MARTINEZ, A.; LOARCA-PINA, G.; OOMAH, B. D. Antioxidant Activity in Common Beans (Phaseolus vulgaris L.) \&sect. Journal of Agricultural and Food Chemistry, v. 50, n. 24, p. 6975-6980, 2002.

CASTAÑEDA-ANDRADE, I.; GONZALEZ-SANCHEZ, J.; FRATI-MUNARI, A. C. Hypoglycemic Effect of an Opuntia streptacanta Lemaire Dialysate. Journal of the Professional Association for Cactus Development, v. 2, p. 73-75, 1997.

CEREZAL, P.; DUARTE, G. Use of Skin in the Elaboration of Concentrated Products of Cactus Pear (Opuntia ficus-indica (L.) Miller). Journal of the Professional Association for Cactus Development, v. 7, n. p. 61-83, 2005.

DESHPANDE, S. S.; CHERYAN, M. Evaluation of Vanillin Assay for Tannin Analysis of Dry Beans. Journal of Food Science, v. 50, n. 4, p. 905-910, 1985. http://dx.doi.org/10.1111/j.1365-2621.1985. tb12977.x

DESHPANDE, S. S.; CHERYAN, M. Determination of Phenolic Compounds of Dry Beans Using Vanillin, Redox and Precipitation Assays. Journal of Food Science, v. 52, n. 2, p. 332-334, 1987. http:// dx.doi.org/10.1111/j.1365-2621.1987.tb06606.x

EL HARIRI, B.; SALLÉ, G.; ANDARY, C. Involvement of flavonoids in the resistance of two poplar cultivars to mistletoe (Viscum album L.). Protoplasma, v. 162, n. 1, p. 20-26, 1991. http://dx.doi. org/10.1007/BF01403897

EL KOSSORI, R. L. et al. Composition of pulp, skin and seeds of prickly pears fruit (Opuntia ficus indica sp.). Plant Foods for Human Nutrition (Formerly Qualitas Plantarum), v. 52, n. 3, p. 263-270, 1998. http://dx.doi.org/10.1023/A:1008000232406

FUKUMOTO, L. R.; MAZZA, G. Assessing Antioxidant and Prooxidant Activities of Phenolic Compounds. Journal of Agricultural and Food Chemistry, v. 48, n. 8, p. 3597-3604, 2000. http://dx.doi. org/10.1021/jf000220w

GALATI, E. M. et al. Chemical Characterization and Biological Effects of Sicilian Opuntia ficus indica (L.) Mill. Fruit Juice:\&nbsp; Antioxidant and Antiulcerogenic Activity. Journal of Agricultural and Food Chemistry, v. 51, n. 17, p. 4903-4908, 2003. http://dx.doi. org/10.1021/jf030123d

GALATI, E. M. et al. Antiulcer activity of Opuntia ficus indica (L.) Mill. (Cactaceae): ultrastructural study. Journal of Ethnopharmacology, v. 76, n. 1, p. 1-9, 2001. http://dx.doi.org/10.1016/S03788741(01)00196-9

GIL, M. I. et al. Antioxidant Capacities, Phenolic Compounds, Carotenoids, and Vitamin C Contents of Nectarine, Peach, and Plum Cultivars from California. Journal of Agricultural and Food Chemistry, v. 50, n. 17, p. 4976-4982, 2002. http://dx.doi. org/10.1021/jf020136b

GURRIERI, S. et al. Chemical Characterization of Sicilian Prickly Pear (Opuntia ficus indica) and Perspectives for the Storage of Its
Juice. Journal of Agricultural and Food Chemistry, v. 48, n. 11, p. 5424-5431, 2000. http://dx.doi.org/10.1021/jf9907844

HABIBI, Y.; MAHROUZ, M.; VIGNON, M. R. Isolation and structure of -xylans from pericarp seeds of Opuntia ficus-indica prickly pear fruits. Carbohydrate Research, v. 337, n. 17, p. 1593-1598, 2002. http://dx.doi.org/10.1016/S0008-6215(02)00186-6

HABIBI, Y.; MAHROUZ, M.; VIGNON, M. R. d-Xylans from seed endosperm of Opuntia ficus-indica prickly pear fruits. Comptes Rendus Chimie, v. 8, n. 6-7, p. 1123-1128, 2005. http://dx.doi. org/10.1016/j.crci.2004.11.027

HERNÁNDEZ-PÉREZ, T. et al. Biochemical and Nutritional Characterization of Three Prickly Pear Species with Different Ripening Behavior. Plant Foods for Human Nutrition (Formerly Qualitas Plantarum), v. 60, n. 4, p. 195-200, 2005.

INGLESE, P.; BASILE, F.; SCHIRRA, M. Cactus pear fruit production. In: NOBEL, P. S. (Ed.). Cacti Biology and uses. California:University of California Press, 2002. p. 280.

KATALINIC, V.; MALES, P. Compositional changes in grape polyphenols throughout maturation. Journal of Wine Research, v. 8, n. 3, p. 169, 1997. http://dx.doi.org/10.1080/09571269708718117

KENNEDY, J. A.; MATTHEWS, M. A.; WATERHOUSE, A. L. Changes in grape seed polyphenols during fruit ripening. Phytochemistry, v. 55 , n. 1 , p. $77-85,2000$. http://dx.doi.org/10.1016/S00319422(00)00196-5

KUTI, J. O. Growth and compositional changes during the development of prickly pear fruit. Journal of Horticultural Science, v. 67, n. p. 861-868, 1992.

LEE, J.-C. et al. Antioxidant Property of an Ethanol Extract of the Stem of Opuntia ficus-indica var. Saboten. Journal of Agricultural and Food Chemistry, v. 50, n. 22, p. 6490-6496, 2002. http://dx.doi. org/10.1021/jf020388c

LÓPEZ-GONZÁLEZ, J. J.; FUENTES-RODRÍGUEZ, J. M.; RODRÍGUEZ-GÁMEZ, A. Industrializacion De La Tuna Cardona (Opuntia streptacantha) Prickly Pear Fruit Industrialization (Opuntia streptacantha). Journal of the Proffesional Association of Cactus, v. 2, n. p. 169-175, 1997.

MISSANG, C. E.; GUYOT, S.; RENARD, C. M. G. C. Flavonols and Anthocyanins of Bush Butter, Dacryodes edulis (G. Don) H.J. Lam, Fruit. Changes in Their Composition during Ripening. Journal of Agricultural and Food Chemistry, v. 51, n. 25, p. 7475-7480, 2003. http://dx.doi.org/10.1021/jf0346399

OOMAH, B. D.; CARDADOR-MARTÍNEZ, A.; LOARCA-PIÑA, G. Phenolics and antioxidative activities in common beans $(<\mathrm{I}>$ Phaseolus vulgaris $</ \mathrm{I}>\mathrm{L})$. Journal of the Science of Food and Agriculture, v. 85, n. 6, p. 935-942, 2005. http://dx.doi.org/10.1002/ jsfa.2019

PASTRANA-BONILLA, E. et al. Phenolic Content and Antioxidant Capacity of Muscadine Grapes. Journal of Agricultural and Food Chemistry, v. 51, n. 18, p. 5497-5503, 2003. http://dx.doi. org/10.1021/jf030113c

PIGA, A. Cactus Pear: A Fruit of Nutraceutical and Functional Importance. Journal of the Professional Association for Cactus Development, v. 6, n. p. 9-22, 2004.

PIMIENTA-BARRIOS, E. Prickly pear (Opuntia spp.): A valuable fruit crop for the semi-arid lands of Mexico. Journal of Arid Environments, v. 28, n. 1, p. 1-11, 1994. http://dx.doi.org/10.1016/ S0140-1963(05)80016-3

RAMADAN, M. F.; MÖRSEL, J-T. Oil cactus pear (Opuntia ficus-indica L.). Food Chemistry, v. 82, n. 3, p. 339-345, 2003a. http://dx.doi.org/10.1016/S0308-8146(02)00550-2 
RAMADAN, M. F.; MÖRSEL, J.-T. Recovered lipids from prickly pear [Opuntia ficus-indica (L.) Mill] peel: a good source of polyunsaturated fatty acids, natural antioxidant vitamins and sterols. Food Chemistry, v. 83, n. 3, p. 447-456, 2003b. http://dx.doi. org/10.1016/S0308-8146(03)00128-6

RE, R. et al.. Antioxidant activity applying an improved ABTS radical cation decolorization assay. Free Radical Biology and Medicine, v. 26, n. 9-10, p. 1231-1237, 1999. http://dx.doi.org/10.1016/S08915849(98)00315-3

SÁENZ, C.; SEPÚLVEDA, E. Cactus-Pear Juices. Journal of the Proffesional Association of Cactus, v. 4, n. p. 3-10, 2001.

SAWAYA, W. N. et al. Chemical characterization of prickly pear pulp, Opuntia ficus-indica, and the manufacturing of prickly pear jam. International Journal of Food Science and Technology, v. 18, n. 2, p. 183-193, 1983. http://dx.doi.org/10.1111/j.1365-2621.1983. tb00259.x

SINGLETON, V. L. et al. Analysis of total phenols and other oxidation substrates and antioxidants by means of Folin-Ciocalteu reagent.
Methods in Enzymology, v. 299, p. 152-178, 1999. http://dx.doi. org/10.1016/S0076-6879(99)99017-1

STINTZING, F. C. et al. Color, Betalain Pattern, and Antioxidant Properties of Cactus Pear (Opuntia spp.) Clones. Journal of Agricultural and Food Chemistry, v. 53, n. 2, p. 442-451, 2005. http://dx.doi.org/10.1021/jf048751y

TOMÁS-BARBERÁN, F. A.; ESPÍN, J. C. Phenolic compounds and related enzymes as determinants of quality in fruits and vegetables. Journal of the Science of Food and Agriculture, v. 81, n. 9, p. 853-876, 2001. http://dx.doi.org/10.1002/jsfa.885

TREJO-GONZÁLEZ, A. et al. A purified extract from prickly pear cactus (Opuntia fuliginosa) controls experimentally induced diabetes in rats. Journal of Ethnopharmacology, v. 55, n. 1, p. 27-33, 1996.

WANG, S. Y.; LIN, H.-S. Antioxidant Activity in Fruits and Leaves of Blackberry, Raspberry, and Strawberry Varies with Cultivar and Developmental Stage. Journal of Agricultural and Food Chemistry, v. 48, n. 2, p. 140-146, 2000. http://dx.doi.org/10.1021/ jf9908345 